\title{
The Effects for Delaying Banana Seedling Growth through Spraying Growing Retardants on Stem Apex
}

\author{
Shenghe Chang1,2\#, Zhengjing Wu ${ }^{3 \#, ~ Q i ~ Z e n g " \#, ~ J i n g y i ~ Z h a n g " \#, ~ W e i ~ S u n ~}{ }^{1,2}$, Lan Qiao3, \\ Haiyan Shu1,2* \\ ${ }^{1}$ Haikou Experimental Station, Chinese Academy of Tropical Agricultural Sciences, Haikou, China \\ ${ }^{2}$ The Key Lab of Hainan Banana Genetics and Breeding, Haikou, China \\ ${ }^{3}$ School of Forestry, Henan University of Science and Technology, Luoyang, China \\ Email: *plantfood772@hotmail.com
}

How to cite this paper: Chang, S.H., Wu, Z.J., Zeng, Q., Zhang, J.Y., Sun, W., Qiao, L. and Shu, H.Y. (2019) The Effects for Delaying Banana Seedling Growth through Spraying Growing Retardants on Stem Apex. American Journal of Plant Sciences, 10, 813-825.

https://doi.org/10.4236/ajps.2019.105059

Received: April 16, 2019

Accepted: May 27, 2019

Published: May 30, 2019

Copyright $\odot 2019$ by author(s) and Scientific Research Publishing Inc. This work is licensed under the Creative Commons Attribution-NonCommercial International License (CC BY-NC 4.0). http://creativecommons.org/licenses/by-nc/4.0/

\begin{abstract}
Replanting is always required for banana farmers. Selecting growth retardants is important for banana seedling companies. Stem apex contained many gibberellins. Seven treatments were performed onto stem apex of banana seedlings in this research. Results showed that heights of seedlings sprayed with paclobutrazol $(200 \mathrm{mg} / \mathrm{L})$, dniconazole $(200 \mathrm{mg} / \mathrm{L})$, and dniconazole + brassins $(200$ $\mathrm{mg} / \mathrm{L}+0.1 \mathrm{mg} / \mathrm{L}$ ) were significantly lower than those of seedlings sprayed with water. Paclobutrazol was the ideal retardant for delaying the growth of leaf if stem apex was selected as a treated candidate. Fresh weights of seedlings of all seven treatments were significantly less than that of control. For delaying the growth of fresh weight of banana seedlings, chlormequat chloride $(200 \mathrm{mg} / \mathrm{L})$ was the best choice. Reducing power of roots of seedlings treated with $100 \mathrm{ml}$ of paclobutrazol $(200 \mathrm{mg} / \mathrm{L})$ was significantly higher than that of seedling treated with water. Chlorophyll contents of seedlings treated with growth retardants were significantly higher than that of seedlings treated with water.
\end{abstract}

\section{Keywords}

Banana Seedlings, Growth Retardants, Selecting, Gibberellins

\section{Introduction}

Banana is an important fruit for farmers in southern China. Many people living in southern China lived on banana planting. Southern China belonged to

${ }^{*}$ Corresponding author. 
subtropical monsoon climate, which is always affected by typhoon in summer and autumn [1] [2]. Banana production is often cut because of typhoon. Sometimes, after blown by typhoon, all of banana plants lodge and no banana fruit could be got in some banana plantation. At this time, fresh banana seedlings were wanted for replanting. The work for culturing banana seedlings needed about four months. The amounts of banana seedlings were always scheduled. If banana seedlings cannot be sold on time, they had to be scrapped. This increased the cost of seedling companies. However, typhoon cannot be forecasted so early. How to ensure that there are enough banana seedlings can be sold after typhoon and not wasted is a problem to be solved for banana seedling companies.

Growth retardants can delay the growth of plant [3] [4] [5]. If the growth of banana seedlings can be slowed down and kept in nursery shed for more time, the problem that how to ensure that enough banana seedlings can be sold after typhoon and not wasted can be solved. The mechanisms of most growth retardants are to block the synthesis of gibberellins [6]-[11]. Most of gibberellins were synthesized in tender part of plant. If growth retardants can be sprayed on these parts, the synthesis of gibberellins might be blocked effectively and the growth of banana seedling can be delayed. Although some papers had reported that growth retardants could inhibit the growth of plants, the tissues treated were always the whole plants [12] [13] [14] [15] [16]. Stem apex, a tender part of the plant where most gibberellins were synthesized was firstly chosen for treatment in this research. Furthermore, although banana is an important fruit in worldwide trade, the effects of growth retardants on banana seedlings have not been reported before. In this paper, seven treatments of growth retardants were sprayed onto the growth point of banana seedlings. The growth of the seedlings was studied. Results showed that the growth of banana seedlings in nursery shed can be delayed remarkably. The mechanism underlying was also discussed.

\section{Materials and Methods}

\subsection{Materials}

Tissue-culture seedlings of Banana (Musa acuminate AAA Cavendish cv. Brazil) were cultivated in the Center of Seedlings, Chinese Academy of Tropical Agricultural Sciences, Danzhou, China. When the third leaf appeared, seedlings in culturing bottles were transferred to plastic pots (cylinder, the diameter of the base and the height was $45 \mathrm{~cm}$ and $100 \mathrm{~cm}$, respectively.) containing gardening soil. The seedlings were sprayed with water containing macronutrients (10 $\mathrm{mg} / \mathrm{L}$ ) of Murashige \& Skoog medium [17] one time every two days. One month later, the seedlings were treated with growth retardants.

\subsection{Spraying onto the Stem Apex of the Banana Seedlings}

Seven treatments were performed in this research. The treatments were paclobutrazol $(200 \mathrm{mg} / \mathrm{L})$, dniconazole $(200 \mathrm{mg} / \mathrm{L})$, paclobutrazol + brassins $(200$ $\mathrm{mg} / \mathrm{L}+0.05 \mathrm{mg} / \mathrm{L})$, paclobutrazol + diethyl aminoethyl hexanoate $(200 \mathrm{mg} / \mathrm{L}+$ 
$10 \mathrm{mg} / \mathrm{L})$, dniconazole + brassins $(200 \mathrm{mg} / \mathrm{L}+0.1 \mathrm{mg} / \mathrm{L})$, dniconazole + diethyl aminoethyl hexanoate $(200 \mathrm{mg} / \mathrm{L}+20 \mathrm{mg} / \mathrm{L})$, chlormequat chloride $(200 \mathrm{mg} / \mathrm{L})$ respectively. One hundred milliliter of solution was sprayed onto the stem apex of seedling every time. Four replicates were done for every treatment. Distilled water was sprayed as control. The treatments were performed every 7 days. The seedlings were sprayed for three times. After 30 days, the materials were collected for measurement.

\subsection{Determination for Chlorophyll Content in Leaves}

Two-hundred milligrams of fresh leaves were ground with $2.5 \mathrm{ml}$ of $95 \%$ ethanol in a mortar. Ten milliliters of $95 \%$ ethanol was added into the serum and continued grounding until the color of the serum showed white. The mixture was stood still for 5 minutes. The serum was filtered using analytical-filter paper. The filtrate was stocked in a brown bottle. The chlorophyll on the mortar and filter paper were washed with ethanol and the solution was also collected in the bottle. Ethanol was added until the volume of the solution was $25 \mathrm{ml}$. The absorbance of the solution was determined using a spectrophotometer at $665 \mathrm{~nm}$ and 649 $\mathrm{nm}$, respectively. The chlorophyll content was calculated according to the following formula.

$$
\begin{aligned}
& \text { Chla }=(13.95 \mathrm{~A} 665-6.88 \mathrm{~A} 649) \times \mathrm{V} / 1000 \mathrm{~W} . \\
& \text { Chlb }=(24.96 \mathrm{~A} 649-7.32 \mathrm{~A} 665) \times \mathrm{V} / 1000 \mathrm{~W} .
\end{aligned}
$$

\subsection{Measurement for Reducing Power of the Seedling Root}

Two-hundred milligrams of root tips were collected and put into a $10-\mathrm{ml}$ beaker. Five milliliters of $0.4 \%$ TTC and $5 \mathrm{ml}$ of phosphate buffer were added. The roots were soaked into the solution completely. After being kept in darkness for 2 hours at $37^{\circ} \mathrm{C}, 2 \mathrm{ml}$ of $1 \mathrm{~mol} / \mathrm{L} \mathrm{H}_{2} \mathrm{SO}_{4}$ was added. The roots were taken out and the water on the roots was soaked up with absorbent paper. The roots were ground with $3.5 \mathrm{ml}$ of ethyl acetate in a mortar. The serum was transferred into a test tube. The debris was washed with ethyl acetate for three times. The solutions were all transferred into the test tube. Ethyl acetate was added until the solution volume was $10 \mathrm{ml}$. the absorbance of the solution was measured using a spectrophotometer at the wavelength of $485 \mathrm{~nm}$. Compared with the standard curve, the reducing quantity of tetrazole was calculated.

\section{Results}

\subsection{Seedling Heights Can Be Inhibited by Paclobutrazol (200 mg/L), Dniconazole (200 mg/L), and Dniconazole + Brassins (200 mg/L + 0.1 mg/L)}

After the stem apex of seedlings were sprayed with growth retardants for 30 days, heights of seedlings sprayed with $100 \mathrm{ml}$ of paclobutrazol $(200 \mathrm{mg} / \mathrm{L})$, dniconazole $(200 \mathrm{mg} / \mathrm{L})$, and dniconazole + brassins $(200 \mathrm{mg} / \mathrm{L}+0.1 \mathrm{mg} / \mathrm{L})$ were significantly lower than those of seedlings sprayed with water (Figure 1). 
The differences between paclobutrazol + brassins, paclobutrazol + diethyl aminoethyl hexanoate, dniconazole + diethyl aminoethyl hexanoate, chlormequat chloride, and those sprayed with water were not remarkable. Among the seven treatments, dniconazole was the best for inhibiting the seedling height. After the stem apex of seedlings were sprayed with growth retardants for 30 days, the height of seedlings sprayed with $100 \mathrm{ml}$ of dniconazole $(200 \mathrm{mg} / \mathrm{L})$ was $19.16 \pm$ $1.2 \mathrm{~cm}$, while that of seedlings sprayed with $100 \mathrm{ml}$ of water was $23.2 \pm 1.0 \mathrm{~cm}$ (Figure 1). The heights of seedlings where the stem apex was sprayed with 100 $\mathrm{ml}$ of dniconazole $(200 \mathrm{mg} / \mathrm{L})$ were significantly lower than those of seedlings on which the stem apex was sprayed with $100 \mathrm{ml}$ of water (Figure 1).

\subsection{The Growth of Leaf Was Delayed by Paclobutrazol (200 mg/L)}

After the seedlings on which the stem apex was sprayed with $100 \mathrm{ml}$ of paclobutrazol $(200 \mathrm{mg} / \mathrm{L})$ for 30 days, leaf length of seedlings was $11.76 \pm 0.2 \mathrm{~cm}$, while that value of seedlings on which the stem apex was sprayed with $100 \mathrm{ml}$ of water was $15.2 \pm 0.8 \mathrm{~cm}$ (Figure 2). Surprisingly, the differences of leaf length of other six treatments and the control were not significant (Figure 2). For leaf width, paclobutrazol was also the best retardant. After the seedlings were treated for 30 days, leaf width of seedlings on which the stem apex was sprayed with $100 \mathrm{ml}$ of paclobutrazol $(200 \mathrm{mg} / \mathrm{L})$ was $5.85 \pm 0.2 \mathrm{~cm}$, while the leaf width of seedlings treated with $100 \mathrm{ml}$ of water was $6.9 \pm 0.4 \mathrm{~cm}$ (Figure 3). Furthermore, the differences among other six treatments and the control were not remarkable (Figure 3). These demonstrated that paclobutrazol was the ideal retardant for delaying the growth of leaf if stem apex was selected as treated candidate.

\subsection{Fresh Weights of Banana Seedlings Treated with Growth Retardants Were Less Than the Control}

After seedlings on which the stem apex was sprayed growth retardants for 30 days, fresh weights of seedlings of all seven treatments were significantly less than that of control (Figure 4). For example, after seedlings on which stem apex

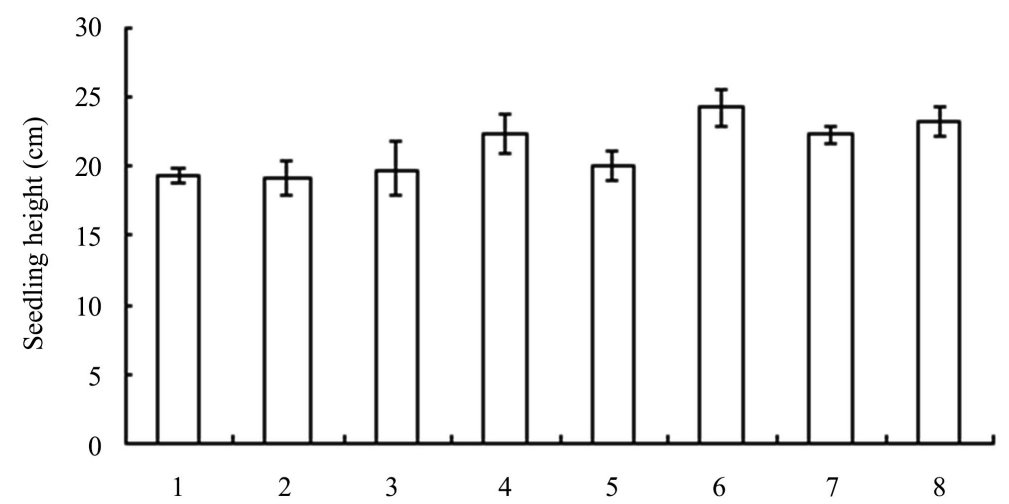

Figure 1. The heights of seedlings treated with different growth retardants. $1-8$ represented paclobutrazol, dniconazole, paclobutrazol + brassins, paclobutrazol + diethyl aminoethyl hexanoate, dniconazole + brassins, dniconazole + diethyl aminoethyl hexanoate, chlormequat chloride, water, respectively. 


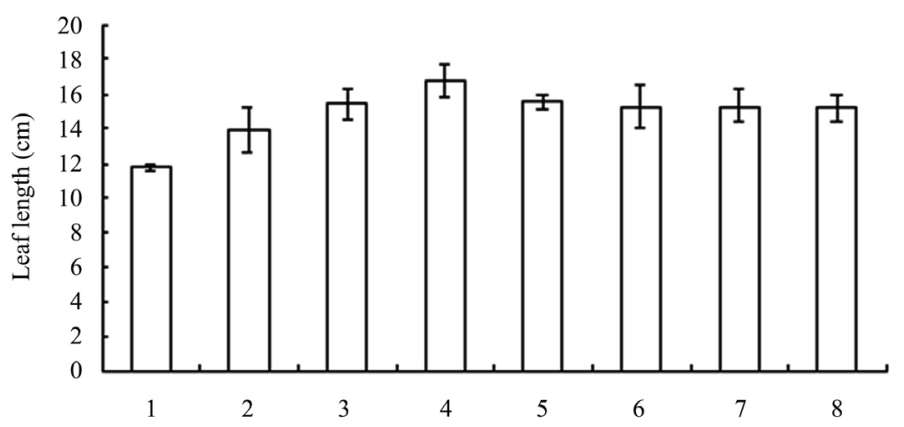

Figure 2. Leaf length of seedlings treated with different growth retardants. 1 - 8 represented paclobutrazol, dniconazole, paclobutrazol + brassins, paclobutrazol + diethyl aminoethyl hexanoate, dniconazole + brassins, dniconazole + diethyl aminoethyl hexanoate, chlormequat chloride, water, respectively.

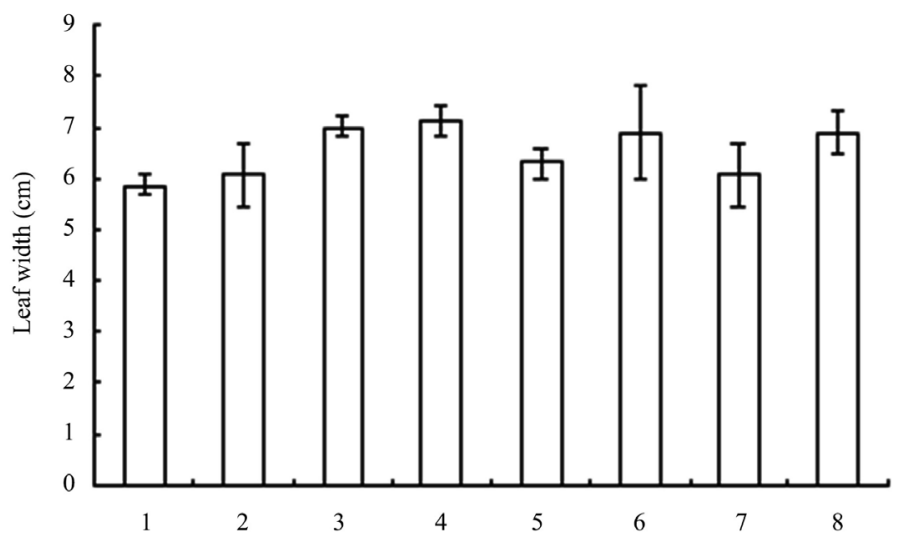

Figure 3. Leaf width of seedlings treated with different growth retardants. 1 - 8 represented paclobutrazol, dniconazole, paclobutrazol + brassins, paclobutrazol + diethyl aminoethyl hexanoate, dniconazole + brassins, dniconazole + diethyl aminoethyl hexanoate, chlormequat chloride, water, respectively.

was sprayed with $100 \mathrm{ml}$ of paclobutrazol + diethyl aminoethyl hexanoate (200 $\mathrm{mg} / \mathrm{L}+10 \mathrm{mg} / \mathrm{L})$ and chlormequat chloride $(200 \mathrm{mg} / \mathrm{L})$, fresh weights of seedlings was $15.89 \pm 0.4 \mathrm{~g}$ and $12.72 \pm 2.1 \mathrm{~g}$ respectively, while that value of seedlings sprayed with $100 \mathrm{ml}$ of water was $22.49 \pm 1.5 \mathrm{~g}$ (Figure 4). Similar phenomenon also happened on fresh weight of roots (Figure 5). However, for fresh weight of above-ground tissues, except values of treatments of paclobutrazol + diethyl aminoethyl hexanoate $(200 \mathrm{mg} / \mathrm{L}+10 \mathrm{mg} / \mathrm{L})$ and chlormequat chloride $(200$ $\mathrm{mg} / \mathrm{L}$ ) were lower than that of control, the differences of other four treatments and control was not remarkable (Figure 6). Generally, for delaying the growth of fresh weight of banana seedlings, chlormequat chloride $(200 \mathrm{mg} / \mathrm{L})$ was the best choice.

\subsection{Pseudostem Diameters of Seedlings Sprayed with Paclobutrazol (200 mg/L), Dniconazole + Brassins $(200 \mathrm{mg} / \mathrm{L}+0.1 \mathrm{mg} / \mathrm{L})$ and Chlormequat Chloride $(200 \mathrm{mg} / \mathrm{L})$ Were Significantly Less Than Those Treated with Water}

After being treated with growth retardants for 30 days, pseudostem diameters of 


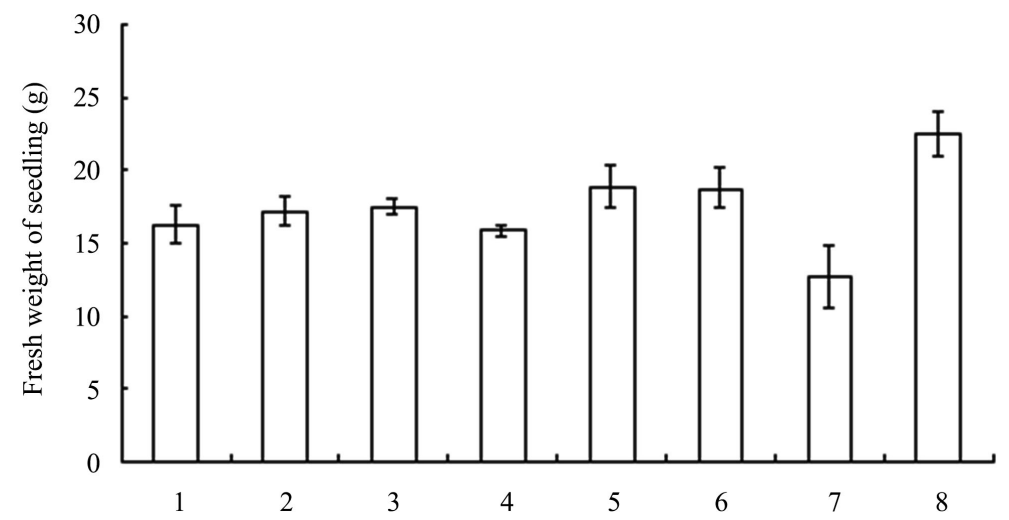

Figure 4. Fresh weight of seedlings treated with different growth retardants. $1-8$ represented paclobutrazol, dniconazole, paclobutrazol + brassins, paclobutrazol + diethyl aminoethyl hexanoate, dniconazole + brassins, dniconazole + diethyl aminoethyl hexanoate, chlormequat chloride, water, respectively.

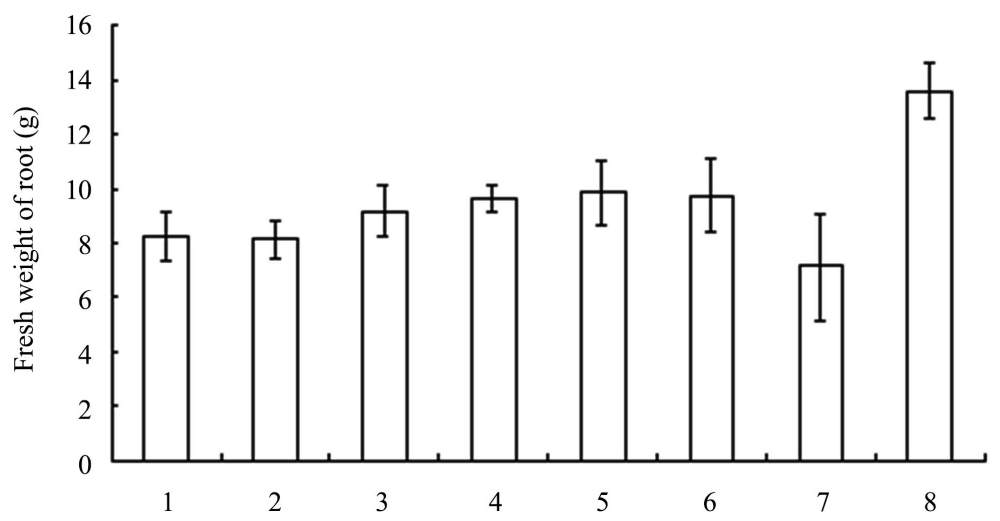

Figure 5. Fresh weights of seedlings treated with different growth retardants. 1 - 8 represented paclobutrazol, dniconazole, paclobutrazol + brassins, paclobutrazol + diethyl aminoethyl hexanoate, dniconazole + brassins, dniconazole + diethyl aminoethyl hexanoate, chlormequat chloride, water, respectively.

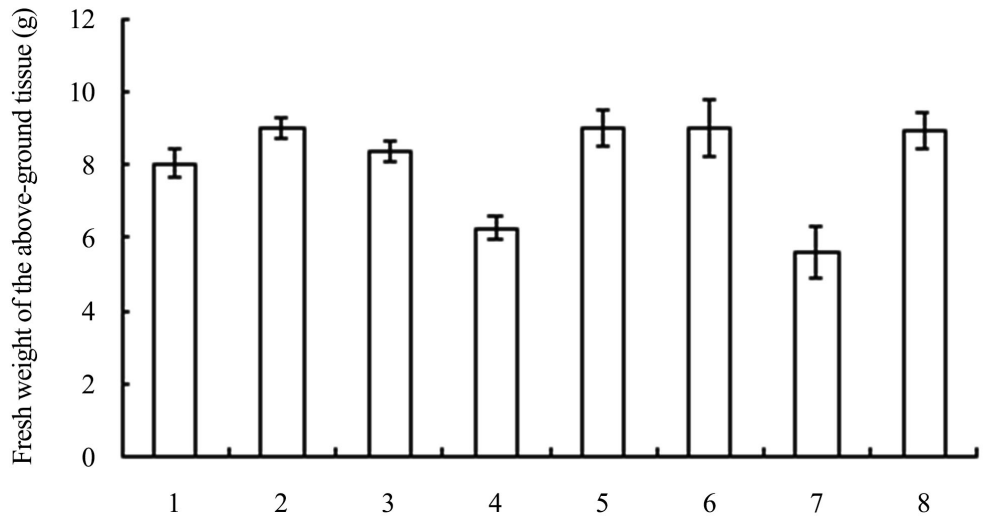

Figure 6. Fresh weights of the above-ground tissues of seedlings treated with different growth retardants. $1-8$ represented paclobutrazol, dniconazole, paclobutrazol + brassins, paclobutrazol + diethyl aminoethyl hexanoate, dniconazole + brassins, dniconazole + diethyl aminoethyl hexanoate, chlormequat chloride, water, respectively. 
seedlings on which stem apex was sprayed with $100 \mathrm{ml}$ of paclobutrazol (200 $\mathrm{mg} / \mathrm{L})$, dniconazole + brassins $(200 \mathrm{mg} / \mathrm{L}+0.1 \mathrm{mg} / \mathrm{L})$ and chlormequat chloride $(200 \mathrm{mg} / \mathrm{L})$ was significantly less than those of seedlings treated with water (Figure 7). Pseudostem diameters of seedlings treated with other growth retardants were similar with those of seedlings treated with water (Figure 7). Among paclobutrazol $(200 \mathrm{mg} / \mathrm{L})$, dniconazole + brassins $(200 \mathrm{mg} / \mathrm{L}+0.1 \mathrm{mg} / \mathrm{L})$ and chlormequat chloride $(200 \mathrm{mg} / \mathrm{L})$, chlormequat chloride $(200 \mathrm{mg} / \mathrm{L})$ was the best treatment for inhibiting the growth of pseudostem diameter.

\subsection{The Growth of Roots of Banana Seedlings Can Be Delayed by Growth Retardants}

After being treated with growth retardants, root volumes of seedlings treated with growth retardants were significantly less than that of control (Figure 8). For example, after banana seedlings were sprayed with $100 \mathrm{ml}$ of chlormequat chloride $(200 \mathrm{mg} / \mathrm{L})$ for 30 days, root volume of banana seedlings was $10 \pm 1.5$ $\mathrm{ml}$, while that value of control was $15 \pm 1.0 \mathrm{ml}$ (Figure 8). Growth volume of banana seedlings can be inhibited by growth retardants remarkably. However, the differences among root lengths of seedlings treated with different treatments were not significant (Figure 9).

\subsection{Reducing Powers of Roots of Banana Seedlings Sprayed with Dniconazole + Diethyl Aminoethyl Hexanoate $(200 \mathrm{mg} / \mathrm{L}+20$ $\mathrm{mg} / \mathrm{L}$ ), Chlormequat Chloride (200 mg/L) Were Remarkably Lower Than Those of Seedlings Treated with Water}

After banana seedlings were sprayed onto stem apex for 30 days, reducing power of roots of seedlings treated with $100 \mathrm{ml}$ of paclobutrazol $(200 \mathrm{mg} / \mathrm{L})$ was significantly higher than that of seedling treated with water (Figure 10). Reducing powers of roots of seedlings treated with $100 \mathrm{ml}$ of dniconazole + diethyl aminoethyl hexanoate $(200 \mathrm{mg} / \mathrm{L}+20 \mathrm{mg} / \mathrm{L})$, chlormequat chloride $(200 \mathrm{mg} / \mathrm{L})$ were lower than that control (Figure 10). Reducing powers of other four treatments were similar with that of control. Among the seven treatments, chlormequat chloride $(200 \mathrm{mg} / \mathrm{L})$ was the best choice for inhibiting reducing power of roots of banana seedlings. After seedlings were sprayed with $100 \mathrm{ml}$ of chlormequat chloride $(200 \mathrm{mg} / \mathrm{L})$ on the stem apex for 30 days, reducing power of roots of seedlings was $0.05 \pm 0.02 \mathrm{mg} / \mathrm{g}$.h, while that value of control was $0.13 \pm 0.02$ $\mathrm{mg} / \mathrm{g} . \mathrm{h}$ (Figure 10).

\subsection{Chlorophyll Contents of Banana Seedlings Treated with Growth Retardants Were Higher Than That of Control}

Chlorophyll A contents of seedlings treated with growth retardants were significantly higher than that of seedlings treated with water (Figure 11). Similar phenomenon also happened on chlorophyll content of banana seedlings (Figure 12). However, the trend of chlorophyll $B$ content of banana seedlings was different from the above two characters (Figure 13). After the seedlings were 
treated for 30 days, chlorophyll B content of seedlings treated with $100 \mathrm{ml}$ of dniconazole + brassins $(200 \mathrm{mg} / \mathrm{L}+0.1 \mathrm{mg} / \mathrm{L})$ was $0.23 \pm 0.03 \mathrm{mg} / \mathrm{g}$. Chlorophyll B content of seedlings treated with water was $0.36 \pm 0.02 \mathrm{mg} / \mathrm{g}$ (Figure 13). chlorophyll B content of seedlings treated with dniconazole + brassins $(200$ $\mathrm{mg} / \mathrm{L}+0.1 \mathrm{mg} / \mathrm{L}$ ) was significantly lower than that of control (Figure 13). At the same time, chlorophyll B contents of seedlings treated with paclobutrazol (200 $\mathrm{mg} / \mathrm{L})$, dniconazole $(200 \mathrm{mg} / \mathrm{L})$, paclobutrazol + brassins $(200 \mathrm{mg} / \mathrm{L}+0.05$ $\mathrm{mg} / \mathrm{L})$, paclobutrazol + diethyl aminoethyl hexanoate $(200 \mathrm{mg} / \mathrm{L}+10 \mathrm{mg} / \mathrm{L})$, dniconazole + diethyl aminoethyl hexanoate $(200 \mathrm{mg} / \mathrm{L}+20 \mathrm{mg} / \mathrm{L})$ were significantly higher than that of control (Figure 13). The differences between chlorophyll B content of seedlings treated with chlormequat chloride $(200 \mathrm{mg} / \mathrm{L})$ and that of control was not remarkable (Figure 13). These showed that all of the seven growth retardants treatments can increase chlorophyll content in seedlings. Dniconazole + brassins $(200 \mathrm{mg} / \mathrm{L}+0.1 \mathrm{mg} / \mathrm{L})$ had the effect on inhibiting the the synthesis of chlorophyll B.

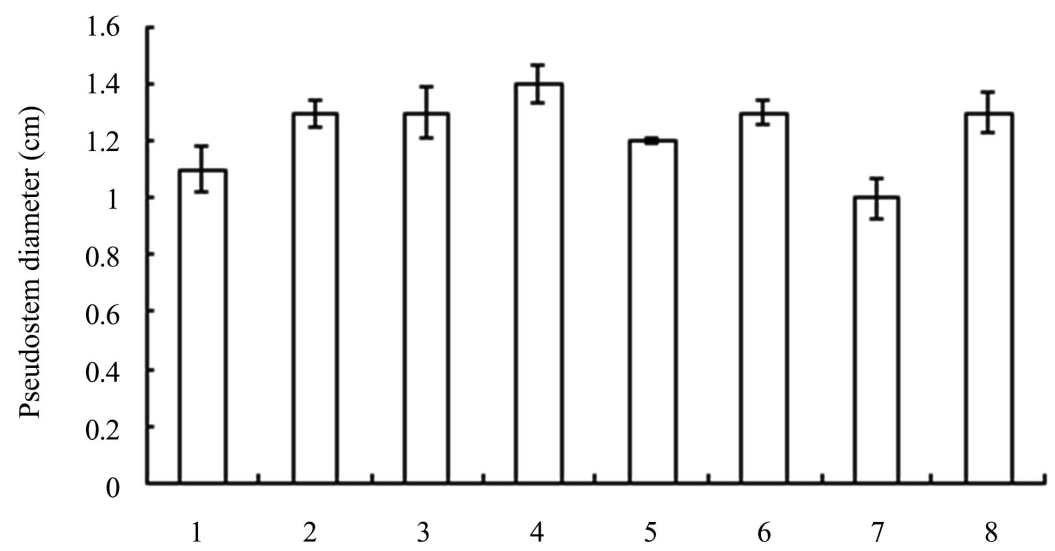

Figure 7. Pseudostem diameters of seedlings treated with different growth retardants. 1 8 represented paclobutrazol, dniconazole, paclobutrazol + brassins, paclobutrazol + diethyl aminoethyl hexanoate, dniconazole + brassins, dniconazole + diethyl aminoethyl hexanoate, chlormequat chloride, water, respectively.

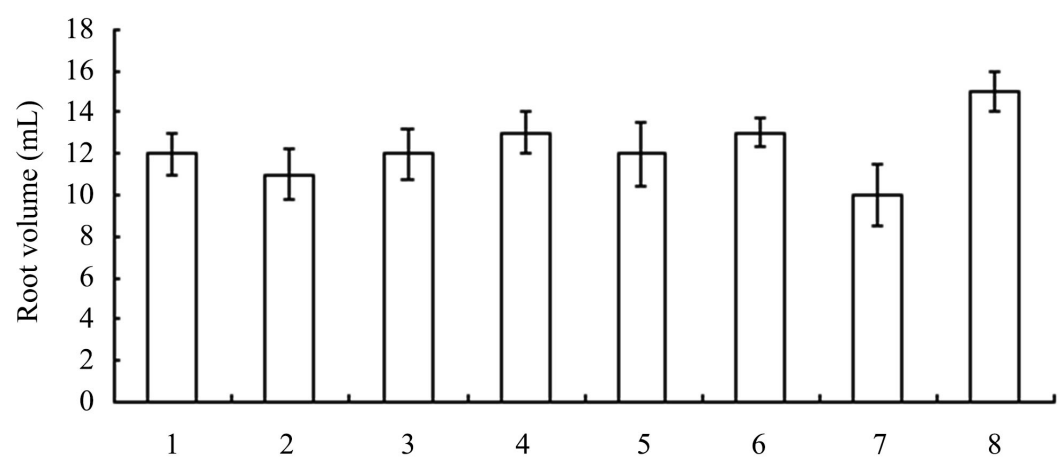

Figure 8. Root volumes of seedlings treated with different growth retardants. $1-8$ represented paclobutrazol, dniconazole, paclobutrazol + brassins, paclobutrazol + diethyl aminoethyl hexanoate, dniconazole + brassins, dniconazole + diethyl aminoethyl hexanoate, chlormequat chloride, water, respectively. 


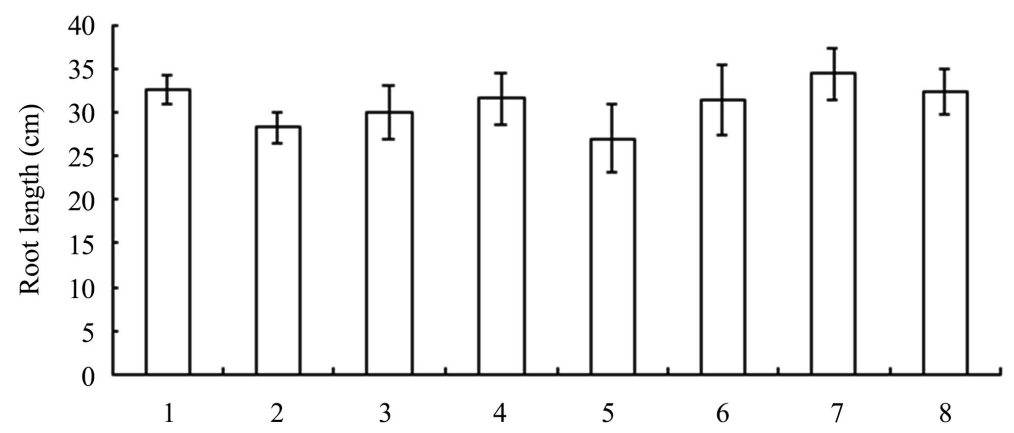

Figure 9. Root length of seedlings treated with different growth retardants. $1-8$ represented paclobutrazol, dniconazole, paclobutrazol + brassins, paclobutrazol + diethyl aminoethyl hexanoate, dniconazole + brassins, dniconazole + diethyl aminoethyl hexanoate, chlormequat chloride, water, respectively.

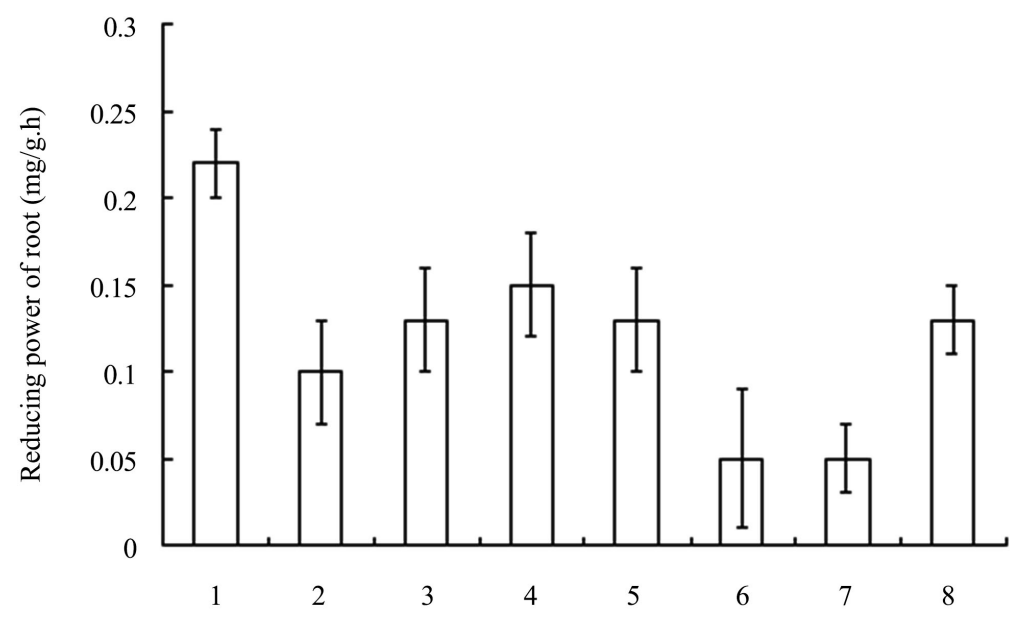

Figure 10. Reducing powers of the roots of seedlings treated with different growth retardants. 1 - 8 represented paclobutrazol, dniconazole, paclobutrazol + brassins, paclobutrazol + diethyl aminoethyl hexanoate, dniconazole + brassins, dniconazole + diethyl aminoethyl hexanoate, chlormequat chloride, water, respectively.

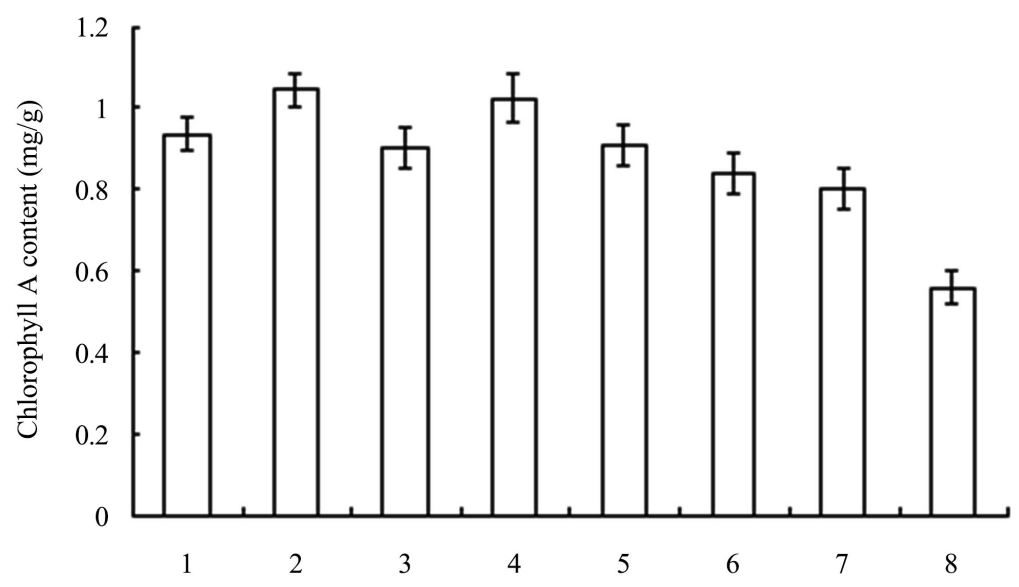

Figure 11. Chlorophyll A contents of seedlings treated with different growth retardants. 1 - 8 represented paclobutrazol, dniconazole, paclobutrazol + brassins, paclobutrazol + diethyl aminoethyl hexanoate, dniconazole + brassins, dniconazole + diethyl aminoethyl hexanoate, chlormequat chloride, water, respectively. 


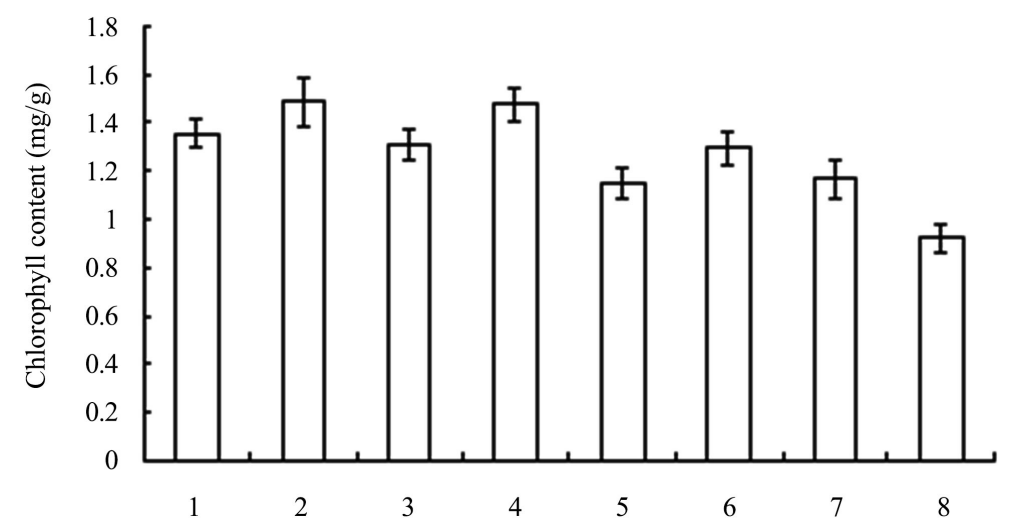

Figure 12. Chlorophyll contents of seedlings treated with different growth retardants. 1 8 represented paclobutrazol, dniconazole, paclobutrazol + brassins, paclobutrazol + diethyl aminoethyl hexanoate, dniconazole + brassins, dniconazole + diethyl aminoethyl hexanoate, chlormequat chloride, water, respectively.

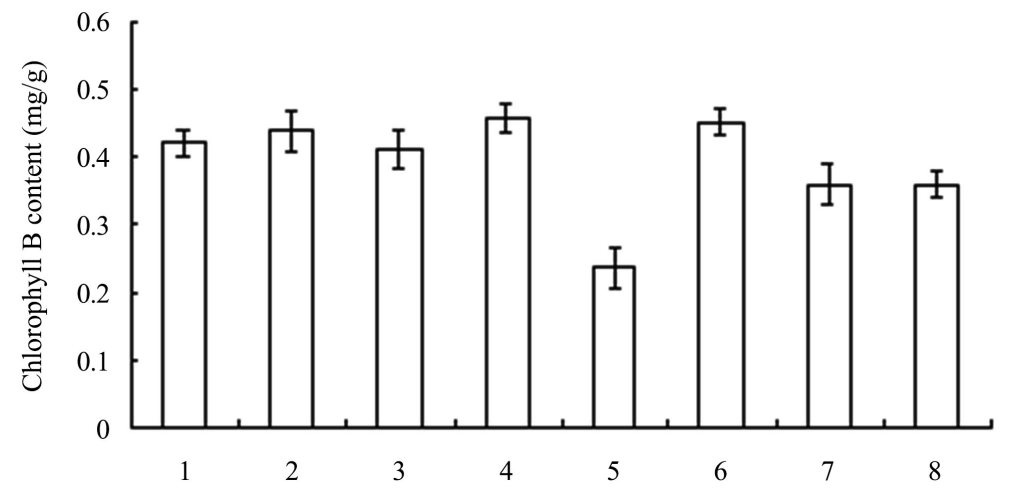

Figure 13. Chlorophyll B contents of seedlings treated with different growth retardants. 1 - 8 represented paclobutrazol, dniconazole, paclobutrazol + brassins, paclobutrazol + diethyl aminoethyl hexanoate, dniconazole + brassins, dniconazole + diethyl aminoethyl hexanoate, chlormequat chloride, water, respectively.

\section{Discussion}

Gibberellin and auxin are mains phytohormones for controlling plant growth. Most of plant growth retardants can block the synthesis of gibberellins [6]-[11]. Gibberellin can restore the dwarf mutants of pea and maize to normal height [18] [19] [20]. If there were no gibberellins in plant, the stem will not be extended, the leaves will not be enlarged, the flower will not develop and seed will not set [21].

The biosynthesis of gibberellins in plant included three steps: the biosynthesis of ent-kaurene, ent-kaurene was oxidized and formed GA12-aldehyde, GA12-aldehyde was oxidized and formed different gibberellins [22] [23] [24] [25] [26]. These steps happened in proplastid, endoplasmic reticulum, and cytoplasm, respectively [22] [23] [24] [25] [26].

Paclobutrazol inhibits the activity of ent-kaurene oxidase, an enzyme in the gibberellins biosynthetic pathway [13]. Paclobutrazol application can inhibit vegetative growth of rice plants and increase chlorophyll content [14]. Sumit et al. 
[15] reported paclobutrazol application significantly decreased plant height of Camelina sativa. Similarly, paclobutrazol decreased gibberellin content in the leaves when applied to rice plant during preanthesis [16]. We found that the seedling height of banana seedlings were significantly lower than those of control. Chlorophyll content in the leaves of banana seedlings treated with paclobutrazol was higher than that of control. The increased chlorophyll content treated with paclobutrazol might be from minimized damage caused by reactive oxygen and changes in the levels of carotenoids, ascorbate and the ascorbate peroxidase [12].

Chlormequat chloride inhibit the biosynthesis of gibberellins through inhibiting the enzyme CPP-synthase [10] [11]. This enzyme catalyze the the process that geranylgeranyl diphosphate was cyclased and form ent-copalyl diphosphate. If this process was blocked, ent-copalyl diphosphate can not be formed. And then, ent-kaurene can not be biosynthesized.

Among the tissues of plant, fresh and young tissues contained more gibberellins. After the stem apex of seedlings were sprayed with growth retardants for 30 days, heights of seedlings sprayed with paclobutrazol $(200 \mathrm{mg} / \mathrm{L})$, dniconazole $(200 \mathrm{mg} / \mathrm{L})$, and dniconazole + brassins $(200 \mathrm{mg} / \mathrm{L}+0.1 \mathrm{mg} / \mathrm{L})$ were significantly lower than those of seedlings sprayed with water. paclobutrazol was the ideal retardant for delaying the growth of leaf if stem apex was selected as treated candidate. Fresh weights of seedlings of all seven treatments were significantly less than that of control. For delaying the growth of fresh weight of banana seedlings, chlormequat chloride $(200 \mathrm{mg} / \mathrm{L})$ was the best choice. Reducing power of roots of seedlings treated with $100 \mathrm{ml}$ of paclobutrazol $(200 \mathrm{mg} / \mathrm{L})$ was significantly higher than that of seedling treated with water. Chlorophyll contents of seedlings treated with growth retardants were significantly higher than that of seedlings treated with water. But the differences between chlorophyll B content of seedlings treated with chlormequat chloride $(200 \mathrm{mg} / \mathrm{L})$ and that of control was not remarkable. The mechanisms underlying these phenomena needed to be studied in the future.

\section{Conclusion}

Seven treatments were performed onto stem apex of banana seedlings in this research. Results showed that heights of seedlings sprayed with paclobutrazol (200 $\mathrm{mg} / \mathrm{L})$, dniconazole $(200 \mathrm{mg} / \mathrm{L})$, and dniconazole + brassins $(200 \mathrm{mg} / \mathrm{L}+0.1$ $\mathrm{mg} / \mathrm{L}$ ) were significantly lower than those of seedlings sprayed with water. Paclobutrazol was the ideal retardant for delaying the growth of leaf if stem apex was selected as a treated candidate. Fresh weights of seedlings of all seven treatments were significantly less than that of control. Reducing power of roots of seedlings treated with $100 \mathrm{ml}$ of paclobutrazol $(200 \mathrm{mg} / \mathrm{L})$ was higher than that of seedling treated with water. Chlorophyll contents of seedlings treated with growth retardants were higher than that of seedlings treated with water. For delaying the growth of fresh weight of banana seedlings, chlormequat chloride (200 $\mathrm{mg} / \mathrm{L}$ ) was the best choice. 


\section{Acknowledgements}

This work was supported by the Key Research and Developmental Plan Item of Hainan Province (No. ZDYF2018072).

\section{Conflicts of Interest}

The authors declare no conflicts of interest regarding the publication of this paper.

\section{References}

[1] Shu, H., Sun, W., Wang, Z., Yin, M., Han, Q., Zhou, Z., Dai, M., Jin, Z., Li, J. and Chang, S. (2016) The Possible Analysis for Breeding Banana Varieties with High Resistance to Typhoon. Molecular Plant Breeding, 14, 1-11.

[2] Chang, S., Sun, W., Xu, G., Wei, Q., Li, J. and Shu, H. (2017) Enhancing Lodging Resistance of Banana Plant by Transforming 4-coumarate: CoA Ligase Gene Mu4CL15. Molecular Plant Breeding, 15, 1-11.

[3] Brown, R.G.S., Kawaide, H., Yang, Y.Y., Rademacher, W. and Kamiya, Y. (1997) Daminozide and Prohexadione Have Similar Modes of Action as Inhibitors of Late Stages of Gibberellin Metabolism. Physiologia Plantarum, 101, 309-313.

[4] Evans, L.T., King, R.W., Mander, L.N., Pharis, R.P. and Duncan, K.A. (1994) The Differential Effects of C-16, 17-Dihydro Gibberellins and Related Compounds on Stem Elongation and Flowering in Lolium temulentum. Planta, 193, 107-114. https://doi.org/10.1007/BF00191613

[5] Fletcher, R.A., Gilley, A., Sankhla, N. and Davis, T.D. (1999) Triazoles as Plant Growth Regulators and Stress Protectants. In: Janick, J., Ed., Horticultural Reviews, John Wiley \& Sons, Chichester, 55-138. https://doi.org/10.1002/9780470650776.ch3

[6] Tolbert, N.E. (1960) (2-Chloroethyl)-Trimethylammonium Chloride and Related Compounds as Plant Growth Substances. I. Chemical Structure and Bioassay. The Journal of Biological Chemistry, 235, 475-479.

[7] Tolbert, N.E. (1960) (2-Chloroethyl)-Trimethylammonium Chloride and Related Compounds as Plant Growth Substances. II. Effect on Growth of Wheat. Plant Physiology, 35, 380-385. https://doi.org/10.1104/pp.35.3.380

[8] Zeeh, B., König, K.H. and Jung, J. (1974) Development of a New Plant Growth Regulator with Biological Activity Related to CCC. Kemia, Helsinki, 621-623.

[9] Garrod, J.F., Hewitt, H.G., Copping, L.G. and Greenwood, D. (1980) A New Group of Ternary Sulphonium Growth Retardants. See Ref., 25A, 67-74.

[10] Benveniste, P. (1986) Sterol Biosynthesis. Annual Review of Plant Physiology, 37, 275-308. https://doi.org/10.1146/annurev.pp.37.060186.001423

[11] Hedden, P. (1990) The Action of Plant Growth Retardants at the Biochemical Level. In: Pharis, R.P. and Rood, S.B. Eds., Plant Growth Substances 1988, Springer, Berlin, Heidelberg, 322-332. https://doi.org/10.1007/978-3-642-74545-4_38

[12] Tesfahun, W. (2018) A Review on: Response of Crops to Paclobutrazol Application. Tesfahun, Cogent Food \& Agriculture, 4, Article ID: 1525169. https://doi.org/10.1080/23311932.2018.1525169

[13] Kondhare, K.R., Hedden, P., Kettlewell, P.S., Farrell, A.D. and Monaghan, J.M. (2014) Use of the Hormone-Biosynthesis Inhibitors Fluridone and Paclobutrazol to Determine the Effects of Altered Abscisic Acid and Gibberellin Levels on 
Pre-Maturity $\alpha$-Amylase Formation in Wheat Grains. Journal of Cereal Science, 60, 210-216. https://doi.org/10.1016/j.jcs.2014.03.001

[14] Dewi, K., Agustina, R.Z. and Nurmalika, F. (2016) Effects of Blue Light and Paclobutrazol on Seed Germination, Vegetative Growth and Yield of Black Rice (Oryza sativa L. 'Cempo Ireng'). Journal of Biotropia, 23, 85-96. https://doi.org/10.11598/btb.2016.23.2.478

[15] Sumit, K., Ghatty, S., Satyanarayana, J., Guha, A., Chaitanya, B.S.K. and Reddy, A.R. (2012) Paclobutrazol Treatment as a Potential Strategy for Higher Seed and Oil Yield in Field-Grown Camelina sativa L. Crantz. BMC Research Notes, 5, 137. https://doi.org/10.1186/1756-0500-5-137

[16] Syahputra, B.A.S., Sinniah, U.R., Rastan, S.O. and Ismail, M.R. (2013) Changes in Gibberellic Acid (GA) Content in 3 Oryza sativa due to Paclobutrazol Treatment. Journal Food Pharmaceutical Sciences, 1, 14-17.

[17] Murashige, T. and Skoog, F. (1962) A Revised Medium for Rapid Growth and Bioassays with Tobacco Tissue Cultures. Physiologia Plantarum, 15, 473-497. https://doi.org/10.1111/j.1399-3054.1962.tb08052.x

[18] Brian, P.W., Elson, G.W., Hemming, H.G. and Radley, M. (1954) The Plant Growth Promoting Properties of Gibberellic Acid, a Metabolic Product of the Fungus, gibberella fujikuroi. Journal of the Science of Food and Agriculture, 5, 602-612. https://doi.org/10.1002/jsfa.2740051210

[19] Brian, P.W. and Hemming, H.G. (1955) The Effect of Gibberellic Acid on Shoot Growth and Pea Seedlings. Physiologia Plantarum, 8, 669-681. https://doi.org/10.1111/j.1399-3054.1955.tb07760.x

[20] Phinney, B.O. (1956) Growth Response of Single-Gene Dwarf Mutants in Maize to Gibberellic Acid. Proceedings of the National Academy of Sciences of the United States of America, 42, 185-189. https://doi.org/10.1073/pnas.42.4.185

[21] Stowe, B.B. and Yamaki, T. (1957) The History and Physiological Action of the Gibberellins. Annual Review of Plant Physiology, 8, 181-216. https://doi.org/10.1146/annurev.pp.08.060157.001145

[22] Graebe, J.E. (1987) Gibberellin Biosynthesis and Control. Annual Review of Plant Physiology, 38, 419-465. https://doi.org/10.1146/annurev.pp.38.060187.002223

[23] Hedden, P. and Kamiya, Y. (1997) Gibberellin Biosynthesis: Enzymes, Genes and Their Regulation. Annual Review of Plant Physiology and Plant Molecular Biology, 48, 431-460. https://doi.org/10.1146/annurev.arplant.48.1.431

[24] Hedden, P. and Proebsting, W.M. (1999) Genetic Analysis of Gibberellin Biosynthesis. Plant Physiology, 119, 365-367. https://doi.org/10.1104/pp.119.2.365

[25] MacMillan, J. (1997) Biosynthesis of the Gibberellin Plant Hormones. Natural Product Reports, 14, 221-243. https://doi.org/10.1039/np9971400221

[26] Ross, J.J. (1994) Recent Advances in the Study of Gibberellin Mutants. Plant Growth Regulation, 15, 193-206. https://doi.org/10.1007/BF00029892 